\title{
OŻYWIAJĄCA OBECNOŚĆ DUCHA ŚWIĘTEGO WE WSPÓLNOTACH KOŚCIOŁA
}

\section{A LIVING PRESENCE OF THE HOLY SPIRIT IN THE MOVEMENTS OF THE CHURCH}

The phenomenon of the action of the Holy Spirit has accompanied the Church throughout her history. After the Second Vatican Council, a special influence of the Holy Spirit is noted in the initiated new prayer movements and communities. This study aims to show the functioning of small communities, the mechanisms of personal and group activities that contribute to deepening the faith of believers.

Key words: Holy Spirit, Church, movements, Second Vatican Council, St. John Paul II, communities prayer, Renewal in the Holy Spirit.

\section{Wstęp}

„Żyjemy w pięknych czasach”, tak wielu z nas powtarza te słowa. Ale jako ludzie wierzący musimy zdawać sobie $z$ tego sprawę, że te "piękne czasy” to dar Pana Boga. On, który działa w Trzech Osobach: Boga Ojca, Syna Bożego Jezusa Chrystusa i Ducha Świętego. Pan Jezus w zapowiedzi zesłania Ducha Świętego powiedział do Apostołów: „Nie wasza to rzecz znać czasy i chwile, które Ojciec ustalił swoją władzą, ale gdy Duch Święty zstąpi na was, otrzymacie Jego moc i będziecie moimi świadkami w Jerozolimie i w całej Judei, i w Samarii, i aż po krańce ziemi" (Dz 1, 7-8). Fenomenu działania Ducha 
Świętego doświadczał Kościół przez całe swe dzieje, a w ostatnich czasach, zwłaszcza po Soborze Watykańskim II, działa poprzez powstawanie nowych grup i wspólnot modlitewnych w całym Kościele. Mając jednak do czynienia z ludźmi o różnych charakterach i kulturze, należy analizować i ewentualnie korygować w grupach i we wspólnotach zachowania członków wspólnot, ale przede wszystkim poprzez nowe formy i struktury grup wspólnotowych prowadzić do pozytywnych przemian w ludziach, w ich życiu osobistym, we wspólnotach, które sobie wybrały i w swoim otoczeniu, a także pozytywnie wpływać na społeczeństwo.

Niniejsze opracowanie ma na uwadze ukazanie funkcjonowania małych wspólnot, mechanizmy działań osobistych i grupowych, przyczyniających się do pogłębienia wiary ludzi wierzących.

\section{Obecność Ducha Świętego w Starym i Nowym Testamencie Pisma Świętego}

Już w Starym Testamencie zaraz na początku Księgi Rodzaju jest mowa o obecności Ducha Pańskiego: „Na początku Bóg stworzył niebo i ziemię. Ziemia zaś była bezładem i pustkowiem: ciemność była nad powierzchnią bezmiaru wód, a Duch Boży unosił się nad wodami” (Rdz 1, 1-2). Z kolei fantastyczna zapowiedź proroka Izajasza o przyjściu Mesjasza wprost mówi o wyjątkowym obdarzeniu Go przez Ducha Świętego: „I wyrośnie różdżka z pnia Jessego, wypuści się odrośl z jego korzeni. I spocznie na niej Duch Pański, duch mądrości i rozumu, duch rady i męstwa, duch wiedzy i bojaźni Pańskiej” (Iz 11, 1-2). I znowu prorok Izajasz w Pierwszej pieśni Stugi Pańskiego zapowiada przyjście Mesjasza, na którym spocznie Duch Boży: „Oto mój sługa, którego podtrzymuję, Wybrany mój, w którym mam upodobanie. Sprawiłem, że Duch mój na nim spoczął; On przyniesie narodom Prawo" (Iz 42, 1). Prorok Izajasz w wielu miejscach swej prorockiej księgi odwołuje się do nadejścia i działania Ducha Świętego. Dla ilustracji jeszcze jedno proroctwo wypowiedziane przez Izajasza, a które później Pan Jezus podczas modlitewnego spotkania w synagodze w Nazarecie odniesie do siebie ${ }^{1}$ : „Duch Pana Boga nade mną, bo Pan mnie namaścił. Posłał mnie, by głosić dobrą nowinę ubogim, by opatrywać rany serc złamanych, by zapowiadać wyzwolenie jeńcom i więźniom swobodę: aby obwieszczać rok łaski Pańskiej" (Iż 61, 1-2). Ponadto trzeba powiedzieć, że obecność Ducha Świętego i Jego działanie jest w Starym Testamencie ukazane w bardzo wielu księgach i proroctwach.

\footnotetext{
Zob. Łk 4, 18-21: „Dziś spełniły się te słowa Pisma, któreście słyszeli” (w. 21).
} 
Tymczasem w Nowym Testamencie obecność Ducha Świętego uwidacznia się w najważniejszych wydarzeniach związanych z życiem Pana Jezusa i pierwotnego Kościoła. Przy Zwiastowaniu Najświętszej Maryi Pannie ujawnia się Duch Święty jako dawca życia naszemu Zbawicielowi. Oto Archanioła Gabriel zapowiada narodzenie Syna Bożego: „Oto poczniesz i porodzisz Syna, któremu nadasz imię Jezus. Będzie On wielki i zostanie nazwany Synem Najwyższego” (Łk 1, 31-32). Na wątpliwości Maryi, jak się to stanie, skoro nie zna męża, Anioł Jej odpowiedział: „Duch Święty zstąpi na Ciebie i moc Najwyższego okryje Cię cieniem. Dlatego też Święte, które się narodzi, będzie nazwane Synem Bożym" (Łk 1, 35). Podczas wizyty u Elżbiety, swojej krewnej oczekującej narodzin Dziecięcia - Jana Chrzciciela - Elżbieta doświadcza wyjątkowego wydarzenia: „Gdy Elżbieta usłyszała pozdrowienie Maryi, poruszyło się dzieciątko w jej łonie, a Duch Święty napełnił Elżbietę” (Łk 1, 41). Kolejny raz uobecnia się Duch Święty podczas ofiarowania Pana Jezusa w świątyni, gdy starzec Symeon pod wpływem Ducha Świętego przychodzi do świątyni jerozolimskiej, bowiem „Jemu Duch Święty objawił, że nie ujrzy śmierci, aż zobaczy Mesjasza Pańskiego. Z natchnienia więc Ducha przyszedł do świątyni” (Łk 2, 26-27). Kolejne bardzo ważne wydarzenie w życiu Jezusa to moment, gdy Duch Święty zstąpił na Niego, gdy przyjmował chrzest z rąk św. Jana Chrzciciela w Jordanie (zob. Łk 3, 21-22). Z kolei w Ewangelii wedtug św. Jana czytamy o darze Ducha Świętego dla Apostołów: „Jeżeli Mnie miłujecie, będziecie zachowywać moje przykazania. Ja zaś będę prosił Ojca, a innego Parakleta da wam, aby z wami był na zawsze. Ducha prawdy, którego świat przyjąć nie może, ponieważ Go nie widzi ani nie zna. Ale wy Go znacie, ponieważ u was przebywa i w was będzie" (J 14, 15-17). Natomiast po Zmartwychwstaniu Pan Jezus mówi do Apostołów, aby nie odchodzili z Jerozolimy, ale żeby oczekiwali obietnicy Ojca: „Słyszeliście o niej ode mnie - [mówił] - Jan chrzcił wodą, ale wy wkrótce zostaniecie ochrzczeni Duchem Świętym” (Dz 1, 4-5). I ten moment zaraz po Wniebowstąpieniu Pana Jezusa, Dzieje Apostolskie tak dokładnie opisują: „Kiedy nadszedł wreszcie dzień Pięćdziesiątnicy, znajdowali się wszyscy razem na tym samym miejscu. Nagle dał się słyszeć z nieba szum, jakby uderzenie gwałtownego wichru i napełnił cały dom, w którym przebywali. Ukazały się im też jakby języki ognia, które się rozdzielały, i na każdym z nich spoczą [jeden]. I wszyscy zostali napełnieni Duchem Świętym, i zaczęli mówić obcymi językami, tak jak im Duch pozwalał mówić” (Dz 2, 1-4).

Tak więc bardzo widoczna i czynna obecność Ducha Świętego ujawniła się u początków chrześcijaństwa. Ta obecność Ducha Świętego miała przede wszystkim charakter wspólnototwórczy, bowiem „trwali oni (pierwsi chrześcijanie) w nauce Apostołów i we wspólnocie, w łamaniu chleba i w modlitwach. Bojaźń ogarniała każdego, gdyż Apostołowie czynili wiele znaków i cudów. 
Ci wszyscy, którzy uwierzyli, przebywali razem i wszystko mieli wspólne" (Dz 2, 42-44).

\section{Aktualność małych grup kościelnych i motywy przynależności}

Duch Święty pozostaje na stałe w Kościele i nie opuszcza go w jego dziejach. Tym bardziej, że potwierdzeniem tego są przecież działania Ducha Świętego tak bardzo widoczne także dzisiaj. Jego obecność dała się odczuć podczas zwołania Soboru Watykańskiego II. Twierdzi się nawet, że w erze posoborowej jeszcze bardziej uwidacznia się działanie Ducha Świętego w ożywieniu aktywności wiernych świeckich. Na dowód tego przytacza się rozwój wielu i niekiedy bardzo zróżnicowanych wspólnot w Kościele katolickim jako przykład na działanie Ducha Świętego. Czas po Soborze Watykańskim stał się niejako bramą otwartą do tworzenia się wspólnot. Papież św. Paweł VI mówi o nowości wnoszonej przez Sobór Watykański II, bowiem Kościół przeżywa „wiosnę ruchów”, a Papież św. Jan Paweł II mówiąc o powstających grupach kościelnych po Soborze Watykańskim II, stwierdza, że „grupy te stanowią dla Kościoła jutra wielką nadzieję" '. Święty Jan Paweł II potwierdza w encyklice Redemptor hominis możliwość egzystencji ludzkiej jako życia osobowego, wspólnotowego i społecznego ${ }^{3}$.

\section{Ruch Odnowy w Duchu Świętym}

Warto więc przykładowo powiedzieć kilka słów chociażby o fantastycznym rozwoju Ruchu Odnowy w Duchu Świętym. Początki Odnowy w Duchu Świętym sięgają 1967 roku. Jak pisze Edward D. O'Connor, dwaj świeccy profesorowie Uniwersytetu Duquesne w Pittsburghu w Stanach Zjednoczonych, nie widząc rezultatów w swoich apostolskich poczynaniach, postanowili wzajemnie za siebie się modlić sekwencją do Ducha Świętego ze Mszy św. z uroczystości Zesłania Ducha Świętego. Blisko rok odmawiali tę modlitwę za siebie wzajemnie. Spotkali się oni obaj także z innymi osobami w lutym 1967 i relacjonując swoje przeżycia wszyscy obecni doznali głębokiej religijnej przemiany, doświadczając bardzo osobistego kontaktu z żywym Chrystusem. Pojawiły się u nich, jak w czasach apostolskich dary Ducha Świętego w postaci charyzmatów: dar języków, prorokowania, rozpoznawania duchów ${ }^{4}$. Ruch charyzmatyczny rozwijał się bardzo szybko na całym świecie. Czym to wytłumaczyć? Ruch ten nawiązywał do autentycznych aspektów życia chrześcijańskiego tak

2 Jan Pawel II, Catechesi tradendae o katechizacji w naszych czasach [16 X 1979], 47.

3 Jan Paweł II, Redemptor hominis u początku papieskiej posługi [4 III 1979], 14.

4 Zob. Edward D. O'Connor, Ruch charyzmatyczny w Kościele Katolickim, Warszawa 1984, s. 111-112. 
bardzo widocznych w pierwotnym Kościele. Odnowa w Duchu Świętym podkreśla te aspekty, które rodziły się wśród uczestników spotkań modlitewnych, a mianowicie: miłości, radości, pokoju, cierpliwości, braterstwa i stawały się źródłem pogłębienia ich autentycznego życia chrześcijańskiego. Dla uzupełnienia tego błyskawicznego rozwoju Ruchu Odnowy w Duchu Święty, należy dodać, że dla uczczenia Roku Świętego w 1975 roku w Rzymie powołano jedną organizację dla tego ruchu dla całego Kościoła, dzisiaj pod nazwą Międzynarodowych Katolickich Służb Odnowy Charyzmatycznej (International Catholic Charismatic Renewal Services) z siedzibą w Rzymie. Na rodzące się pytania odnośnie do owych spektakularnych darów wśród uczestników spotkań modlitewnych, tak w starożytnym Kościele i w dzisiejszych wspólnotach charyzmatycznych, adekwatną odpowiedź daje św. Paweł w Pierwszym Liście do Koryntian: „Nie chciałbym, bracia, byście trwali w niewiedzy co do darów duchowych. [...] Otóż zapewniam was, że nikt pozostając pod natchnieniem Ducha Bożego, nie może mówić: «Niech Jezus będzie przeklęty». Nikt też nie może powiedzieć bez pomocy Ducha Świętego: «Panem jest Jezus» Różne są dary łaski, lecz ten sam Duch: różne też są rodzaje posługiwania, ale jeden jest Pan; różne są wreszcie działania, lecz ten sam Bóg, sprawca wszystkiego we wszystkich. Wszystkim zaś objawia się Duch dla wspólnego dobra. Jednemu dany jest przez Ducha dar mądrości słowa, drugiemu umiejętność poznawania według tego samego Ducha, innemu dar czynienia cudów, innemu proroctwo, innemu rozpoznawanie duchów, innemu dar języków i wreszcie innemu łaska tłumaczenia języków. Wszystko zaś sprawia jeden i ten sam Duch, udzielając każdemu tak, jak chce" (1 Kor, 12, 1-11). Te słowa Apostoła Narodów są adekwatną odpowiedzią na ewentualne wątpliwości wobec darów Ducha Świętego uwidaczniające się w zebraniach modlitewnych wspólnot Odnowy w Duchu Świętym. Jednocześnie należy dodać, że te nadzwyczajne dary charyzmatyczne jako nadnaturalne dary Ducha Świętego są dawane przez Niego do budowania wspólnoty ${ }^{5}$ U wiernych, którzy otrzymują dary charyzmatyczne, dokonuje się wielka przemiana, jako dar głębszego poznania Boga, doświadczenia Jego bliskości, bardzo osobisty z Nim związek, wręcz przyjacielskie z Nim przebywanie. Bóg przestaje być dla tych osób kimś anonimowym albo kimś dalekim, wręcz odwrotnie Bóg dla osób związanych w Odnową w Duchu Świętym staje się bardzo bliski i kochany.

Zob. M. Olszewski, Ks. Stanisław Szczepura pierwszym opiekunem Odnowy w Duchu Świętym w Archidiecezji Białostockiej, [w:] W stużbie Kościoła, (red.) Z. T. Klimaszewski, Białystok 2011, s. 207. 


\section{Powstawanie nowych małych grup kościelnych}

Do każdego fenomenu rodzącej się czy już istniejącej małej grupy, czy wspólnoty należy podchodzić krytycznie i oceniać ich sposób funkcjonowania. Jest jasne, że każda epoka ma swoje uwarunkowania i problemy i że w każdym historycznym czasie należy przyglądać się temu, co się dokonuje w społeczeństwie i w poszczególnych grupach. Jednakże stwierdzić możemy, że powstawanie grup, stowarzyszeń, wspólnot zawsze bazowało na ludzkiej potrzebie bycia razem, podejmowania razem wspólnych dzieł i osiągania wspólnych celów ${ }^{6}$. Patrząc od strony religijnej możemy również stwierdzić, że w każdej historycznej epoce, ciesząc się Bożymi darami, rozwijały się i tworzyły własne struktury, aby osiągnąć zamierzone cele, czego przykładem są różne zgromadzenia zakonne, czy chociażby wspomniany Ruch Odnowy w Duchu Świętym.

W ostatnich dziesiątkach lat świat przeżywa ogromne przemiany, co się zaznacza rozwojem nauk, techniki, informatyki i kultury, jak też przemian ustrojowych zmierzających ku demokratyzacji życia. Kościół również przeżywa wielkie przemiany, zwłaszcza pod wpływem Soboru Watykańskiego II, czego dowodem mogą być rodzące się rozmaite nowe ruchy i wspólnoty kościelne. Motywy, którymi kierują się poszczególne osoby w poszukiwaniu życia wspólnotowego, można odnaleźć w obecnym zatomizowanym świecie, gdy tymczasem ludzie poszukują takiego miejsca, takiego środowiska, takiej grupy, w których byliby zauważeni, docenieni, zostaliby wysłuchani, a ich problemy byłyby wzięte pod uwagę. Dzisiaj w epoce wszechobecnych mediów ludzie oczekują, aby słowa były bez podtekstów i kamuflaży i miały swoją prawdziwą wartość.

W kontaktach wewnętrznych grupy ma się do czynienia z konkretnymi ludźmi, mającymi swoje problemy, oczekiwania, swoje sprawy. Ponadto wielu poszukuje zaspokojenia własnych wewnętrznych potrzeb, takich jak poczucia bezpieczeństwa, przyjaźni, życzliwości, zrozumienia i uznania ze strony innych. Zaspokojenie tych potrzeb widzą ludzie właśnie we wspólnocie, w małej grupie, w gronie osób znających się i życzliwych. Zaspokojenie tych rozmaitych potrzeb i oczekiwań prowadzi do poczucia przynależności do danej wspólnoty. Jednakże przemiany widoczne w społeczeństwie i w Kościele, powstawanie nowych ruchów i nowych struktur, domagają się nowej wizji wspólnoty, która potrzebuje aktywnego udziału wszystkich członków danej grupy, domaga się także demokratycznego przewodnictwa - leadership - a w związku z tym decentralizacji służb i posług w Kościele, szerszego delegowania władzy, szerszego uczestnictwa w podejmowaniu decyzji i realnych problemów grupy, czy

$6 \quad$ Zob. J. Przybyłowski, Duszpasterstwo grupowe w kontekście zadan wychowawczych, „Teologia Praktyczna” 5(2004), s. 25-38. 
wspólnoty? ${ }^{7}$ Jeżeli w powstawaniu grup i wspólnot jest wiele spontaniczności, to jednak ich rozwój i funkcjonowanie potrzebuje odpowiedniego kierownictwa do animowania życia wspólnoty. I tu wyłaniają się dwie ważne sprawy do właściwego i owocnego funkcjonowania, a także rozwoju wspólnot i małych grup, mianowicie odpowiedniego i odpowiedzialnego animatora oraz respektowania pewnych zasad w funkcjonowaniu grupy.

\section{Animator we wspólnocie}

Źródłosłów słowa „animować” zawiera znaczenie ożywiania, pobudzania do rozwoju, a także „dawanie duszy” danej działalności. To jest właśnie zadanie animatora w grupie. Jego rola, zwłaszcza w grupie dynamicznej, jest szczególna, ponieważ każda osoba w grupie odznacza się własnym charakterem, własnymi cechami, a także specjalnymi darami. Istnieje więc potrzeba zauważenia tych cech i darów ku rozwojowi całej wspólnoty. Jest to, oczywiście, pierwszorzędne zadanie animatora każdej grupy.

Można spotkać się jednakże ze złym pojmowaniem roli animatora we wspólnocie. Dzieje się to wówczas, gdy animator - lider - przejmuje samodzielnie dyrygowanie wspólnotą, a także poprzez bezwzględne wymagane posłuszeństwo podporządkowuje sobie działalność członków grupy. Sytuacje takie spotyka się nie tylko w sektach, może to dotyczyć także grup kościelnych, gdzie dochodzi nawet do odejścia od Kościoła oficjalnego. W takich przypadkach to lider jest władczy, który podporządkowuje sobie wspólnoty o charakterze kościelnym i niekiedy staje na froncie kolizyjnym z władzami diecezjalnymi, najbardziej wobec ordynariusza diecezji. Tymczasem grupa kościelna ma sprzyjać rozwojowi Kościoła, pogłębiać wiarę uczestników wspólnot i dbać o wspólne dobro grupy, parafii i w ogóle Kościoła. Naczelną zasadą Kościoła urzędowego jest kontrolowanie prawowierności w wyznawaniu wiary i poprawności funkcjonowania grup i wspólnot.

Pełnienie funkcji animatora w grupie jest bardzo złożone. Animator powinien być katalizatorem w różnych ewentualnych napięciach we wspólnocie, ułatwiać wszystkim członkom grupy szerokie uczestnictwo w życiu wspólnoty, pobudzać ducha inicjatywy, a jednocześnie ułatwiać wspólne podejmowanie decyzji. Jego postawę można nazwać dyspozycyjnością dla poszczególnych członków grupy. Powstaje więc pytanie, jakimi cechami powinien odznaczać się animator - lider wspólnoty? Są to najpierw cechy osobiste wrodzone, a najważniejszą z nich

P. Grieger, La creatività: strumento del rinnovamento. Applicazioni comunitarie, Roma 1977. s. 72: „Ogni organismo collettivo ha bisogno di partecipazione attive die suoi membri per esistere e per crescere. Ciò e tanto più vero, quando si tratta di una comunità di vita“. 
jest otwartość na drugiego człowieka. A tak ogólnie oczekuje się od animatora następujących cech:

- zrozumienia drugiego człowieka, czyli bycia otwartym i gotowym do wysłuchania innych oraz pozostawać przychylnym do poszczególnych członków wspólnoty;

- obiektywności w ocenianiu ludzi;

- widzenia innych i ich spraw obiektywnie, a nie poprzez pryzmat własnych odczuć;

- opanowania i kontrolowania siebie;

- inicjatywy własnej oraz dostrzegania inicjatyw innych członków wspólnoty;

- ducha współpracy w grupie bez wyróżniania kogokolwiek;

- odwagi i optymizmu;

- zaufania do siebie i do innych ${ }^{8}$.

Analizując różnorodność cech i charakterów ludzi, socjologowie zauważają, że wśród pełniących funkcje animatorów są przynajmniej dwa typy, dwa style prowadzenia wspólnoty: typ władczy, autorytarny, który mówi dużo na spotkaniach i jego idee są przeważnie akceptowane i przyjmowane bez większego oporu ze strony członków grupy. Drugi typ to animator lubiany, współpracujący z innymi członkami wspólnoty, potrafi zebrać idee i pomysły innych, jak też tworzyć klimat sympatii 9 . Oba style prowadzenia grupy mają zarówno pozytywne jak i negatywne strony. W stylu autorytarnym prowadzenia grupy istnieją większe szanse na przeprowadzenie podjętych zadań, ale niekiedy ze szkodą na rzecz trwałości grupy, bowiem grupa staje się niezdolna do dalszego funkcjonowania, co się wyraża małą aktywnością i brakiem inicjatywy ze strony członków wspólnoty ${ }^{10}$. Tymczasem w kooperatywnym prowadzeniu wspólnoty początkowy entuzjazm działania może się zamienić w rozluźnienie więzów grupy i tworzenie frakcji pośród jej członków, dotyczy to zwłaszcza wspólnot o liczniejszej przynależności. Te rozważania na temat funkcjonowania małych grup tak świeckich jak i kościelnych nie muszą odnosić się w stu procentach do wszystkich grup i wspólnot. Także prowadzenie jakiejkolwiek wspólnoty nie ma na względzie charakterystycznych cech animatora. Animatorzy wyłaniają się ze wspólnot po jakimś czasie ich funkcjonowania. Ich osoby nabierają znaczenia po pewnym czasie, gdy członkowie wspólnot widzą ich jako osoby nadające się do kierowania wspólnotą.

$8 \quad$ P. Grieger, Lanimazione comunitaria, Roma 1976, s. 52-54.

9 N. Glatzel, Gemeindebildung und Gemeindestruktur. Ein Beitrag der christlichen Sozialwissenschaften zu einer Kernfrage des christlichen Lebens, Muenchen-Paderborn-Wien 1976, s. 111 (Abhandlungen zur Sozialethik, 14).

10 Tamże, s. 117. 


\section{Funkcjonowanie małych wspólnot i grup modlitewnych}

W powstawaniu i funkcjonowaniu grupy można zauważyć pewne etapy jej dojrzewania i wzajemnego rozumienia się członków spotkań. Są to najpierw warunki zewnętrzne umożliwiające pozytywne funkcjonowanie grupy. W pierwszym rzędzie to liczba członków, która waha się od pięciu do dziesięciu osób. W grupie poniżej pięciu osób powstają trudności do stworzenia rzeczywistości socjalnej, natomiast grupa powyżej dziesięciu osób ma tendencję do podziałów. Ponadto dla dobra uczestników spotkań, dla stworzenia dobrej atmosfery w samym spotkaniu modlitewnym tworząc warunki sprzyjające interakcji międzyosobowej zaleca się, aby uczestnicy mogli sobie patrzeć w oczy, być twarzą w twarz ze sobą. Z kolei, aby spotkanie mogło przynosić pozytywne owoce, warunkiem jest jego dobre przygotowanie i przebieg spotkania podany do wiadomości uczestników. W trakcie spotkania powinien być zachowany klimat wolności, ale także świadomej samodyscypliny. Spotkanie przebiega w miarę poprawnie, gdy uczestnicy czują się wysłuchani i zrozumiani, a przede wszystkim czują się bezpieczni w wyrażaniu swoich opinii, odczuć i pomysłów ${ }^{11}$.

Niemniej ważne są czynniki psychologiczne funkcjonowania małej grupy. W prowadzeniu grupy należy brać pod uwagę fakt, co jest ważnym zadaniem każdego animatora i lidera, że jakkolwiek grupa składa się z osób, które indywidualnie mogą być uważane za dojrzałe, nie tworzą ipso facto dojrzałej struktury. Dojrzałość grupy osiąga się po dłuższym i powolnym procesie, który wymaga wielu spotkań i przejścia kilku koniecznych etapów normalnego wzrastania grupy i dojrzewania uczestników.

Można także wyróżnić parę etapów dojrzewania grupy i członków spotkań. Najpierw chodzi o wzajemne poznanie się, które prowadzi do stworzenia komunikacji interpersonalnej. Animacja polega więc nie tyle na studiowaniu przepisów, ale powinna prowadzić do osobistej przemiany uczestników spotkań. Po etapie wzajemnego poznania się członkowie grupy odkrywają własny status we wspólnocie, który prowadzi również do wzajemnej akceptacji. Ten etap można nazwać „zrzuceniem maski”, co prowadzi do atmosfery wzajemnej akceptacji. Po tych faktach następuje ogólne odprężenie i w zasadzie wszyscy uczestnicy spotkań zaczynają zabierać głos, czy w grupie modlitewnej modlić się swoimi słowami wielbiąc Boga z głębi swego serca. Dzięki temu rodzi się nowy duch grupy i jej nowa dynamika. Jeżeli dokonuje się w większym czy też w mniejszym stopniu pozytywna przemiana w grupie, taka wspólnota jest zdolna do podejmowania zaplanowanym zadań, czyli jest gotowa do szerszego działania. Gdy więc nastąpi ta konsolidacja grupy, staje się ona zdolna do własnego rozwoju i do zewnętrznej działalności apostolskiej i ewangelizacyjnej.

$11 \quad$ P. Grieger, L'animazione comunitaria, s. 31. 


\section{Zakończenie}

Fenomen powstawania nowych grup, pomimo coraz większej współczesnej demokratyzacji społeczeństw, wskazuje na poszukiwanie akceptacji człowieka jako osoby, jako czegoś koniecznego do rozwoju osobistego i poczucia wewnętrznego bezpieczeństwa. Kościól jako instytucja założona przez Jezusa Chrystusa i niosąca ludziom Boże Zbawienie, ma ogromne możliwości wspierania tych tendencji i niesienia koniecznej pomocy ludziom. Tendencje te nasiliły się znacznie po Soborze Watykańskim II, a w Kościele są zaliczane do nowego tchnienia Ducha Świętego. Szanse, które stoją przed duchowieństwem i wiernymi chrześcijanami można dobrze wykorzystać przy rozumieniu przedstawionych tutaj mechanizmów funkcjonowania wspólnot. Ważne jest też widzieć rolę, jak i przygotowanie odpowiednich przywódców wspólnot. To wszystko dzieje się pod tchnieniem Ducha Świętego i należy postawić na Jego wsparcie we współczesnej działalności Kościoła, zarówno w duszpasterstwie parafialnym, jak i w działalności wspólnotowej.

Słowa kluczowe: Duch Święty, Kościół, św. Jan Paweł II, małe grupy, wspólnoty modlitewne, Odnowa w Duchu Świętym.

\section{Bibliografia:}

1. Jan Paweł II, Redemptor hominis u początku papieskiej posługi (4 III 1979).

2. Jan Paweł II, Catechesi tradendae o katechizacji w naszych czasach (16 X 1979).

3. Edward D. O'Connor, Ruch charyzmatyczny w Kościele Katolickim, Warszawa 1984.

4. N. Glatzel, Gemeindebildung und Gemeindestruktur. Ein Beitrag der christlichen Sozialwissenschaften zu einer Kernfrage des christlichen Lebens, Muenchen-Paderborn-Wien 1976, s. 111 (Abhandlungen zur Sozialethik, 14).

5. P. Grieger, L'animazione comunitaria, Rzym 1976.

6. P. Grieger, La creativita: strumento del rinnovamento. Applicazioni comunitarie, Rzym 1977.

7. M. Olszewski, Ks. Stanisław Szczepura pierwszym opiekunem Odnowy w Duchu Świętym w Archidiecezji Białostockiej, [w:] W stużbie Kościoła, (red.) Z. T. Klimaszewski, Białystok 2011.

8. J. Przybyłowski, Duszpasterstwo grupowe w kontekście zadań wychowawczych, „Teologia Praktyczna" 5(2004). 